\title{
Stable isotope marking of otoliths during vaccination: a novel method for mass-marking fish
}

\author{
Fletcher Warren-Myers ${ }^{1, *}$, Tim Dempster ${ }^{1}$, Per Gunnar Fjelldal ${ }^{2}$, Tom Hansen ${ }^{2}$, \\ Arne J. Jensen ${ }^{3}$, Stephen E. Swearer ${ }^{1}$ \\ ${ }^{1}$ Department of Zoology, University of Melbourne, Parkville, Victoria 3010, Australia \\ ${ }^{2}$ Institute of Marine Research, Matre Aquaculture Research Station, 5984 Matredal, Norway \\ ${ }^{3}$ Norwegian Institute for Nature Research (NINA), 7485 Trondheim, Norway
}

\begin{abstract}
Tagging or marking of fishes enables the collection of population-based information for ecological research, yet few techniques enable $100 \%$ mark detection success. We tested a new mass-marking technique: otolith marking with enriched stable isotopes delivered during vaccination. Atlantic salmon (Salmo salar) parr were injected in either the abdominal cavity or muscle with a combination of enriched ${ }^{137} \mathrm{Ba},{ }^{86} \mathrm{Sr}$ and ${ }^{26} \mathrm{Mg}$, using 1 of 3 carrier solutions (water, vaccine, vaccine mimic). Laser ablation inductively coupled plasma mass spectrometry of the otoliths indicated that ${ }^{137} \mathrm{Ba}$ and ${ }^{86} \mathrm{Sr}$ isotope enrichment treatments achieved $100 \%$ mark success, with 0 to $34 \%$ success for ${ }^{26} \mathrm{Mg}$, compared to experimental controls. Mark strength was greater when enriched isotopes were injected into the abdominal cavity compared to muscle. Isotope markers did not affect fish condition or survival. Marks could be differentiated with $100 \%$ success from the background levels present in wild parr collected from 22 Norwegian rivers. Stable isotope marking via vaccination with enriched stable isotopes is a mass-marking technique that, once optimised, could allow for cost-effective differentiation of wild and escaped farmed fish for each independent farming area.
\end{abstract}

KEY WORDS: Atlantic salmon · Barium $\cdot$ Escape $\cdot$ Salmo salar $\cdot$ Strontium

\section{INTRODUCTION}

Fish identification markers, whether artificial or natural, are an essential tool for population-based ecological research, particularly for studies of population connectivity (Swearer et al. 1999, Thorrold et al. 2006, Almany et al. 2007), stock identification (Campana 2005, Barnett-Johnson et al. 2007), fish migratory patterns (Kalish 1990, Jones et al. 1999, Kennedy et al. 2002, Elsdon \& Gillanders 2004, Walther \& Limburg 2012) and stock discrimination (Adey et al. 2009, Glover 2010). However, the reliability of a mark or marker-based data can be uncertain depending on the type of identification used. For example, uncertainty may arise due to poor mark retention, mark misidentification, low recapture rates,

\footnotetext{
${ }^{*}$ Corresponding author: fwwm@student.unimelb.edu.au
}

or marker-related effects on growth and survival. As no single marking technique is suitable for all situations, it is important to choose a marker that minimises the uncertainty in fish identification for the particular research question and application.

Markers may be categorised into 2 general groups: natural or artificial. Natural markers include genetic sequences (Glover et al. 2008), elemental composition of otoliths (Kennedy et al. 2000, 2002, Gillanders 2005, Barbee \& Swearer 2007) or scales (Adey et al. 2009), or differences in fish morphology. Natural markers are most suited for investigating population structure in fish species that have enough spatial, biological or environmental variability to effectively differentiate among groups of fish. Natural markers are effective in that they already exist within a fish

() The authors 2014. Open Access under Creative Commons by Attribution Licence. Use, distribution and reproduction are unrestricted. Authors and original publication must be credited. 
population; however, identification and discrimination of groups of fish using natural markers is often limited by the requirement of a large and comprehensive baseline data library to accurately discriminate among groups (e.g. Glover et al. 2008).

Artificial markers, in contrast, require intervention to create the mark and are most suited for marking small numbers of fish $(<1000$ individuals $)$. These include physical markers that are inserted into fish (e.g. anchor: Serafy et al. 1995; disk: Collins et al. 1994; and coded wire tags: Munro et al. 2003) or removal of some part of the fish that does not regrow, e.g. barbels (Collins et al. 1994) and adipose fins (Vander Haegen et al. 2005). These marking techniques, however, can cause physical stress, lesions and compromised swimming ability, with subsequent increases in mortality (Collins et al. 1994, Serafy et al. 1995, Buckland-Nicks et al. 2012). In addition, they are costly and labour-intensive to apply.

The alternative to marking fish individually is to mass-mark. Mass-marking is preferable when marking large numbers of fish (>1000 individuals) is a high priority, as it is less labour-intensive and reduces individual handling stress for fish. Mass-marking has been achieved through otolith thermal marking (Volk et al. 1999); chemical marking by immersion in fluorescent dyes such as tetracycline (Jones et al. 1999), calcein and alizarin red S (Crook et al. 2009); and elemental marking (Farrell \& Campana 1996, Bath et al. 2000). These marking techniques also have issues, such as poor longevity of some chemical dyes (Crook et al. 2009), and up to $40 \%$ inaccuracy in identification of multiple thermal marks (Volk et al. 1999).

Marking with enriched stable isotopes (Thorrold et al. 2006) is a relatively new mass-marking method that can create unique single and multiple markers with $100 \%$ accuracy. Artificial stable isotope 'fingerprint' marks can be created when enough enriched isotope is introduced to significantly change the relative isotopic abundance in the otolith compared to the natural background isotope ratio. Stable isotopes have been used to successfully mark fish embryos (Thorrold et al. 2006, Williamson et al. 2009b), larvae (Woodcock et al. 2011a), and juveniles (Munro et al. 2008, Smith \& Whitledge 2011) by changing the isotopic ratios of barium (Ba) and strontium ( $\mathrm{Sr}$ ) in their otoliths. Stable isotopes of $\mathrm{Ba}$ and $\mathrm{Sr}$ occur naturally in aquatic ecosystems and are detectable in wild fish in ratios that are largely invariant (see reviews by Campana 2005, Gillanders 2005). The one exception is $\mathrm{Sr}$, where low levels of variation in isotope ratios within otoliths have been used to trace movement patterns of fish within freshwater catchments (Kalish
1990, Kennedy et al. 2000, 2002, Elsdon \& Gillanders 2004, Barnett-Johnson et al. 2005). Stable isotope fingerprint marking using $\mathrm{Ba}$ and/or $\mathrm{Sr}$ isotopes can be applied to the individual, or groups of fish, and has been validated in both marine and freshwater fish species using a variety of delivery methods, e.g. via: (1) maternal transfer, where enriched stable isotopes injected into brood stock is passed on to the offspring (Thorrold et al. 2006, Munro et al. 2009, HuelgaSuarez et al. 2012); (2) immersion of larvae or juveniles in an isotope-enriched solution (Smith \& Whitledge 2011, Woodcock et al. 2011a,b); or (3) delivery via isotope-enriched feeds (Woodcock et al. 2013). Marking with enriched stable isotopes of magnesium (Mg) has shown poor mark success via immersion and dietary uptake (Woodcock et al. 2011a, 2012). However, the incorporation of $\mathrm{Mg}$-enriched stable isotopes via direct injection has yet to be investigated and may provide a more successful marking application for $\mathrm{Mg}$ isotopes.

To date, there are no studies on marking with stable isotopes of individual fish during vaccination, or on how injection site or carrier solution affects marking success. Current isotope marking techniques indicate that the delivery method, duration of exposure, and the amount of isotope received influence the uptake of enriched isotopes, and consequently, mark success (Munro et al. 2009, Williamson et al. 2009b, Woodcock et al. 2011a). In addition to validating a stable isotope mark delivery method, knowledge of the natural variability in isotopic ratios for a given species and study system is required before a stable isotope fingerprinting method can be considered to be an effective and accurate individual- or mass-marking tool.

Here, we tested a novel enriched stable isotope marking technique by investigating whether stable isotope otolith fingerprint markers can be combined with routine vaccination of Norwegian farmed Atlantic salmon Salmo salar. We explored this delivery method because escaped fish from aquaculture are a significant environmental problem (Jensen et al. 2010), and accurate methods to differentiate escaped farmed fish from wild fish and the farm of origin would enhance compliance measures. In addition, all 300+ million farmed salmon grown in the sea in Norway each year (Jensen et al. 2010) are vaccinated in the abdominal cavity with an oil-adjuvant vaccine. Hence, during vaccination, isotope markers may be administered in a controlled amount, to individual fish at a specific point in the life history stage, with no extra manual handling in the production process. Consequently, all marking issues, such as the period of iso- 
tope enrichment, the amounts of isotope received, and mark effectiveness, have the potential to be controlled and evaluated at a whole-of-industry scale.

First, we tested whether we could create unambiguous marks through introducing enriched stable isotopes during routine vaccination via 2 injection sites, using a vaccine, a vaccine mimic, or water as a carrier solution to determine whether mark success and strength varied with injection site and carrier solution. Second, we determined if otolith fingerprinting via injection had any adverse side effects by comparing condition and survival of injected fish $10 \mathrm{wk}$ after marking. Finally, we generated a baseline database of variation in the isotopic ratios of $\mathrm{Ba}, \mathrm{Sr}$ and Mg by sampling Atlantic salmon parr from 22 rivers across the latitudinal extent of Norway, which we could use to assess if the artificial otolith fingerprint marks we created could be unambiguously detected relative to wild fish.

\section{MATERIALS AND METHODS}

\section{Enriched stable isotope otolith fingerprinting during vaccination}

Experimental location and fish

The experiment was conducted at the Institute of Marine Research field station, at Matre, in Masfjorden, western Norway $\left(60^{\circ} \mathrm{N}\right)$. Atlantic salmon (AquaGen strain) parr (standard length: $16.2 \pm 0.02 \mathrm{~cm}$ [mean $\pm \mathrm{SE}$ ]; mass: $57.1 \pm 0.07 \mathrm{~g}$ ) were used in the experiment. All fish were passive integrated transponder (pit) tagged with $11 \mathrm{~mm}$ Trovan ID 101 tags (BTS Scandinavia AB) 2 mo prior to the experiment and reared in standard commercial hatchery conditions. Fish in all treatments were in similar condition (Fulton's condition factor $K_{i} F_{11,71}=0.9, \mathrm{p}=0.5$ ) at Day 1 of the experiment. All work was conducted in accordance with the laws and regulations of the Norwegian Regulation on Animal Experimentation 1996.

\section{Experimental design}

We tested if the level of stable isotope enrichment, carrier solution and injection location affected otolith mark success and detectability of $\mathrm{Ba}, \mathrm{Sr}$ and $\mathrm{Mg}$
Table 1. Design of the experiment to test mark success and strength through introducing enriched stable isotopes during routine vaccination of Salmo salar via 2 injection sites (muscle [M] or abdominal avity $[\mathrm{AC}]$ ), using a vaccine (V), a vaccine mimic (VM), or water (W) as a carrier solution. Enrichment: yes $(\mathrm{Y})$ or no $(\mathrm{N})$

\begin{tabular}{|c|c|c|c|c|c|}
\hline \multirow{2}{*}{$\begin{array}{l}\text { Injection } \\
\text { location }\end{array}$} & \multirow{2}{*}{$\begin{array}{c}\text { - Factors } \\
\text { Carrier } \\
\text { solution }\end{array}$} & \multirow[b]{2}{*}{$\begin{array}{c}\text { Isotope } \\
\text { enrichment }\end{array}$} & \multicolumn{3}{|c|}{ Sample sizes $(\mathrm{n})$} \\
\hline & & & $\begin{array}{l}\text { Fish per } \\
\text { treatment }\end{array}$ & $\begin{array}{l}\text { Growth } \\
\text { analysis }\end{array}$ & $\begin{array}{l}\text { Otolith } \\
\text { analysis }\end{array}$ \\
\hline M & W & $\mathrm{Y}$ & 12 & 6 & 6 \\
\hline M & W & $\mathrm{N}$ & 12 & 6 & 6 \\
\hline M & $\mathrm{V}$ & $\mathrm{Y}$ & 12 & 6 & 6 \\
\hline M & $\mathrm{V}$ & $\mathrm{N}$ & 12 & 6 & 5 \\
\hline M & VM & $\mathrm{Y}$ & 12 & 6 & 6 \\
\hline M & VM & $\mathrm{N}$ & 12 & 6 & 5 \\
\hline $\mathrm{AC}$ & W & $\mathrm{Y}$ & 12 & 6 & 6 \\
\hline $\mathrm{AC}$ & W & $\mathrm{N}$ & 12 & 6 & 6 \\
\hline $\mathrm{AC}$ & $\mathrm{V}$ & $\mathrm{Y}$ & 12 & 6 & 6 \\
\hline $\mathrm{AC}$ & $\mathrm{V}$ & $\mathrm{N}$ & 12 & 6 & 6 \\
\hline $\mathrm{AC}$ & VM & $\mathrm{Y}$ & 12 & 6 & 6 \\
\hline $\mathrm{AC}$ & VM & $\mathrm{N}$ & 12 & 6 & 6 \\
\hline
\end{tabular}

isotope fingerprints (Table 1). Atlantic salmon parr were injected with either no isotope, or a combination of 3 enriched stable isotopes, ${ }^{137} \mathrm{Ba}_{1}{ }^{86} \mathrm{Sr}$ and ${ }^{26} \mathrm{Mg}$ (Oak Ridge National Laboratory; www.ornl.gov), each at a concentration of $2 \mu \mathrm{g}$ of isotope per gram of parr average mass. One of 3 carrier solutions was used: (1) water-based (W) carrier solution, which consisted of $100 \%$ Milli-Q water; (2) oil-based vaccine (V) carrier solution, which consisted of $3.5 \%$ Milli-Q water and $96.5 \%$ multi vaccine MINOVA 6 (NORVAX ${ }^{\circledR}$ MINOVA 6, Global Aquatic Animal Health, Thormøhlensgate 55, 5008 Bergen, Norway); and (3) oil emulsion-based vaccine mimic (VM) carrier solution, which consisted of $50 \%$ Milli-Q water and $50 \%$ paraffin oil. Stable isotopes in powder chloride form used for the isotope enrichment treatments were first dissolved in water and then mixed into the final carrier solutions. The VM final carrier solution required the addition of soy lecithin (130 $\mathrm{mg} \mathrm{ml}^{-1} \mathrm{VM}$ solution) and vortexing for $1 \mathrm{~min}$ at $13000 \mathrm{rpm}$ (Ultra-Turrax T25, IKA ${ }^{\odot}$-Labortechnik) to obtain a stable emulsion. Injections were given into the abdominal cavity (AC), approximately $20 \mathrm{~mm}$ behind the pectoral fin on the ventral side of parr, or into the musculature $(M)$, approximately $10 \mathrm{~mm}$ below the dorsal fin on the lefthand side of each fish. Parr were injected with a hypodermic syringe using a $5 \mathrm{~mm}, 27$ gauge vaccination needle with a standard vaccination volume of $0.1 \mathrm{ml}$.

Fish were anaesthetised with Benzoak VET (dose $0.2 \mathrm{ml} \mathrm{l}^{-1}$ of clean hatchery water), identified by their PIT tag number, then weighed, measured (fork length) and injected. After injection, fish were 
placed into one of three $1000 \mathrm{l}$ tanks with equal interspersion of individuals among treatments within each tank (i.e. 4 fish from each treatment per tank). The fish were reared under a $12 \mathrm{~h}$ light: $12 \mathrm{~h}$ dark photoperiod for the first $2 \mathrm{wk}$ post-injection before being switched to $24 \mathrm{~h}$ continuous light for the next 8 wk to induce smoltification. Two weeks after injection, a randomly selected sub-sample of 6 parr per treatment were anaesthetised and identified by their PIT tag number before being weighed, measured (fork length) and then euthanised by anaesthetic overdose. Sagittal otoliths from each fish were dissected and removed, mechanically cleaned of any adhering tissue, air-dried, and stored individually in plastic tubes. The remaining fish $(n=6$ per treatment) were grown for a further $8 \mathrm{wk}$ before they were anaesthetised, weighed, and measured (fork length) to test for differences in growth and condition among treatments. Remaining fish were euthanised by anaesthetic overdose at the final endpoint of the experiment (10 wk post-injection date).

Baseline isotope ratios for Atlantic salmon in Norwegian rivers

Samples of Atlantic salmon parr from 22 rivers spanning the latitudinal extent of Norway were used to determine natural baseline variation in the ratios of ${ }^{134} \mathrm{Ba}:{ }^{138} \mathrm{Ba},{ }^{135} \mathrm{Ba}:{ }^{138} \mathrm{Ba},{ }^{136} \mathrm{Ba}:{ }^{138} \mathrm{Ba},{ }^{137} \mathrm{Ba}:{ }^{138} \mathrm{Ba},{ }^{86} \mathrm{Sr}:{ }^{88} \mathrm{Sr}$, ${ }^{87} \mathrm{Sr}:{ }^{88} \mathrm{Sr}$ and ${ }^{26} \mathrm{Mg}:{ }^{24} \mathrm{Mg}$. These samples had been collected by the Norwegian Institute for Nature Research between 1986 and 2010 and preserved in ethanol. In addition to determining spatial variability, temporal variability was assessed between 1990 and 2010 using samples from 6 randomly selected years from each of the Saltdalselva and Strynselva rivers. Sagittal otoliths from 3 parr per location or year were used for the assessment of baseline ratios.

\section{Otolith preparation}

Sagittal otoliths were cleaned of any remaining organic tissue by immersing in a solution of ultrapure $15 \% \mathrm{H}_{2} \mathrm{O}_{2}$ buffered with $0.1 \mathrm{M} \mathrm{NaOH}$. Following immersion, otoliths were ultra-sonicated (Sonic Clean 250HT) for $5 \mathrm{~min}$ and then left for $6 \mathrm{~h}$ in the cleaning solution. The cleaning solution was then aspirated off and the otoliths were transferred through 3 Milli-Q water rinses, each of which consisted of $5 \mathrm{~min}$ of ultra-sonification and $30 \mathrm{~min}$ resting time.
Otoliths were then air-dried in a laminar flow bench for at least $24 \mathrm{~h}$. Once dry, 1 otolith per fish was fixed, sulcus side down, onto gridded microscope slides using quick-dry cyanoacrylate glue.

\section{Otolith analysis}

Stable isotope analyses were done on a Varian 7700x inductively coupled plasma mass spectrometer (ICP-MS) fitted with a HelEx (Laurin Technic and the Australian National University) laser ablation (LA) system constructed around a Compex 110 (Lambda Physik) excimer laser operating at $193 \mathrm{~nm}$. National Institute of Standards and Technology (NIST) 612 and 610 glass standards doped with trace elements at known concentrations were used to calibrate the system. External precision estimates (\%RSD, Relative Standard Deviation) based on 20 analyses of a MACS3 microanalytical carbonate standard were as follows: ${ }^{134} \mathrm{Ba}:{ }^{138} \mathrm{Ba}=7.37 ;{ }^{135} \mathrm{Ba}:{ }^{138} \mathrm{Ba}=0.81$, ${ }^{136} \mathrm{Ba}:{ }^{138} \mathrm{Ba}=4.51,{ }^{137} \mathrm{Ba}:{ }^{138} \mathrm{Ba}=0.72,{ }^{86} \mathrm{Sr}:{ }^{88} \mathrm{Sr}=0.94$, ${ }^{87} \mathrm{Sr}:{ }^{88} \mathrm{Sr}=1.16$ and ${ }^{26} \mathrm{Mg}:{ }^{24} \mathrm{Mg}=0.60$. Otoliths were run in blocks of 16 samples selected randomly from all treatments and bracketed by analyses of the standard. Samples and standard were analysed in timeresolved mode, using a spot size of $157 \mu \mathrm{m}$, a laser energy setting of $\sim 60 \mathrm{~mJ}$ and a laser repetition rate of $5 \mathrm{~Hz}$. Spot ablation was performed under pure helium (He) $\left(200 \mathrm{ml} \mathrm{min}^{-1}\right)$ to minimise re-deposition of ablated material, and the sample was then entrained into the argon (Ar) $\left(0.95 \mathrm{ml} \mathrm{min}^{-1}\right)$ carrier gas flow to the ICP-MS. Using this method, we were able to quantify the concentrations of ${ }^{134} \mathrm{Ba},{ }^{135} \mathrm{Ba}$, ${ }^{136} \mathrm{Ba}_{1}{ }^{137} \mathrm{Ba},{ }^{138} \mathrm{Ba},{ }^{86} \mathrm{Sr}_{1}{ }^{87} \mathrm{Sr},{ }^{88} \mathrm{Sr}_{,}{ }^{24} \mathrm{Mg},{ }^{26} \mathrm{Mg}$ and ${ }^{43} \mathrm{Ca}$ in the outer region of salmon parr otoliths. Data were processed off-line using a specialised MS Excel template which involved a low-pass filter to remove any spikes (a single scan value $>2 \times$ the median of the adjacent scans), smoothing (a running average of 3 scans) and blank subtracting functions. A correction factor ( $C=R_{\text {true }} / R_{\text {obs }}$, where $R_{\text {true }}$ is the naturally occurring isotope ratio and $R_{\text {obs }}$ is the average isotope ratio measured in either the NIST 612 or NIST 610 standard run before and after each set of 16 samples) was applied to all sample scans to correct for mass bias. NIST 612 was used for ${ }^{137} \mathrm{Ba},{ }^{135} \mathrm{Ba}_{1}{ }^{87} \mathrm{Sr},{ }^{86} \mathrm{Sr}$ and ${ }^{26} \mathrm{Mg}$, and NIST 610 for ${ }^{134} \mathrm{Ba}$ and ${ }^{136} \mathrm{Ba}$. Isotope ratios are expressed as the enriched isotope divided by the most commonly abundant isotope for each element used, so that the measure of enrichment is always expressed as an increase in the enriched isotope relative to the most common isotope. 


\section{Statistical analysis}

Mark detection limits for the isotope ratios ${ }^{137} \mathrm{Ba}:{ }^{138} \mathrm{Ba},{ }^{86} \mathrm{Sr}:{ }^{88} \mathrm{Sr}$ and ${ }^{26} \mathrm{Mg}:{ }^{24} \mathrm{Mg}$ were calculated from the average isotope ratios of fish across all control treatments (i.e. non-enrichment treatments). To ensure a correct classification probability of $99.94 \%$, mark detection limits were set at 3.3 standard deviations (SDs) above the mean observed ratio in all control fish for each enriched isotope used. Because of the inherent instability in isotopic ratios measured on single-detector, ICP-based mass spectrometers, we conservatively set the criteria for detecting a successful mark in the otolith as at least 3 consecutive scans with ratios above the detection limit.

The effects of isotope enrichment ( 0 and $2 \mu \mathrm{g}$ isotope $\mathrm{g}^{-1}$ fish), carrier solution (W, V and VM) and injection location ( $\mathrm{AC}$ and $\mathrm{M}$ ) on the ratios ${ }^{137} \mathrm{Ba}:{ }^{138} \mathrm{Ba}$, ${ }^{86} \mathrm{Sr}:{ }^{88} \mathrm{Sr}$ and ${ }^{26} \mathrm{Mg}:{ }^{24} \mathrm{Mg}$ were analysed using 3-factor ANOVAs with data standardised for initial fish weight. The response variable used was the maximum isotope ratio observed in each fish otolith.

Strength of ${ }^{137} \mathrm{Ba}:{ }^{138} \mathrm{Ba},{ }^{86} \mathrm{Sr}:{ }^{88} \mathrm{Sr}$ and ${ }^{26} \mathrm{Mg}:{ }^{24} \mathrm{Mg}$ mark success for only the isotope enrichment treatments ( $2 \mu \mathrm{g}$ isotope $\mathrm{g}^{-1} \mathrm{fish}$ ) was assessed by testing the effects of carrier solution (W, V and VM) and injection site (AC and $\mathrm{M}$ ) with 2-factor ANOVAs using data standardised for initial fish weight. The response variables used for each fish were the total number of scans with ratios above the detection limit and the average isotope ratio of all scans above the detection limit. A scan is defined as a single laser ablation data point.

The effect of treatment on change in fish condition over the experimental period was analysed with a factorial ANOVA. Carrier solutions (W, V and $\mathrm{VM}$ ), injection location ( $\mathrm{AC}$ and $\mathrm{M}$ ) and stable isotope enrichment ( 0 and $2 \mu \mathrm{g}$ isotope $\mathrm{g}^{-1}$ fish) were treated as fixed factors. The response variable used was change in fish condition and was estimated using Fulton's condition factor $K$. Statistical significance was determined at $\alpha=0.05$ for all ANOVAs.

The baseline ratios ${ }^{134} \mathrm{Ba}:{ }^{138} \mathrm{Ba},{ }^{135} \mathrm{Ba}$ : ${ }^{138} \mathrm{Ba},{ }^{136} \mathrm{Ba}:{ }^{138} \mathrm{Ba},{ }^{137} \mathrm{Ba}:{ }^{138} \mathrm{Ba},{ }^{86} \mathrm{Sr}:{ }^{88} \mathrm{Sr}$, ${ }^{87} \mathrm{Sr}:{ }^{88} \mathrm{Sr}$ and ${ }^{26} \mathrm{Mg}:{ }^{24} \mathrm{Mg}$ for each of the 22 rivers in Norway were expressed as the isotope ratio value (mean $\pm \mathrm{SE}$ ) analysed from 3 fish from each river and each year.

\section{RESULTS}

\section{Mark success}

A mark success of $100 \%$ was achieved with the stable isotopes ${ }^{137} \mathrm{Ba}$ and ${ }^{86} \mathrm{Sr}$ across all enriched isotope treatments, irrespective of injection location, or carrier solution (Figs. 1 \& 2). Mark success for ${ }^{26} \mathrm{Mg}$ in the enriched treatments was poor by comparison. ${ }^{26} \mathrm{Mg}$ mark success ranged from 0 to $34 \%$ and varied among injection location and carrier solutions (Fig. 3). No aberrant ${ }^{137} \mathrm{Ba},{ }^{86} \mathrm{Sr}$ or ${ }^{26} \mathrm{Mg}$ isotope marks were observed above the threshold limit in the nonenriched (control) treatments.

\section{Effect of treatment on isotope ratios}

Maximum recorded isotope ratios were 22 times higher for ${ }^{137} \mathrm{Ba}:{ }^{138} \mathrm{Ba}$ and 2.4 times higher for ${ }^{86} \mathrm{Sr}:{ }^{88} \mathrm{Sr}$ in the enriched treatments compared to the nonenriched treatments $\left({ }^{137} \mathrm{Ba}\right.$ enrichment ratio: $4.84 \pm$ 0.05 [mean $\pm \mathrm{SE}$ ], non-enrichment ratio: $0.22 \pm 0.05$, $F_{1,69}=4164, \mathrm{p}<0.001 ;{ }^{86} \mathrm{Sr}$ enrichment ratio: $0.33 \pm$ 0.02 , non-enrichment ratio: $0.14 \pm 0.02, F_{1,69}=80, \mathrm{p}<$

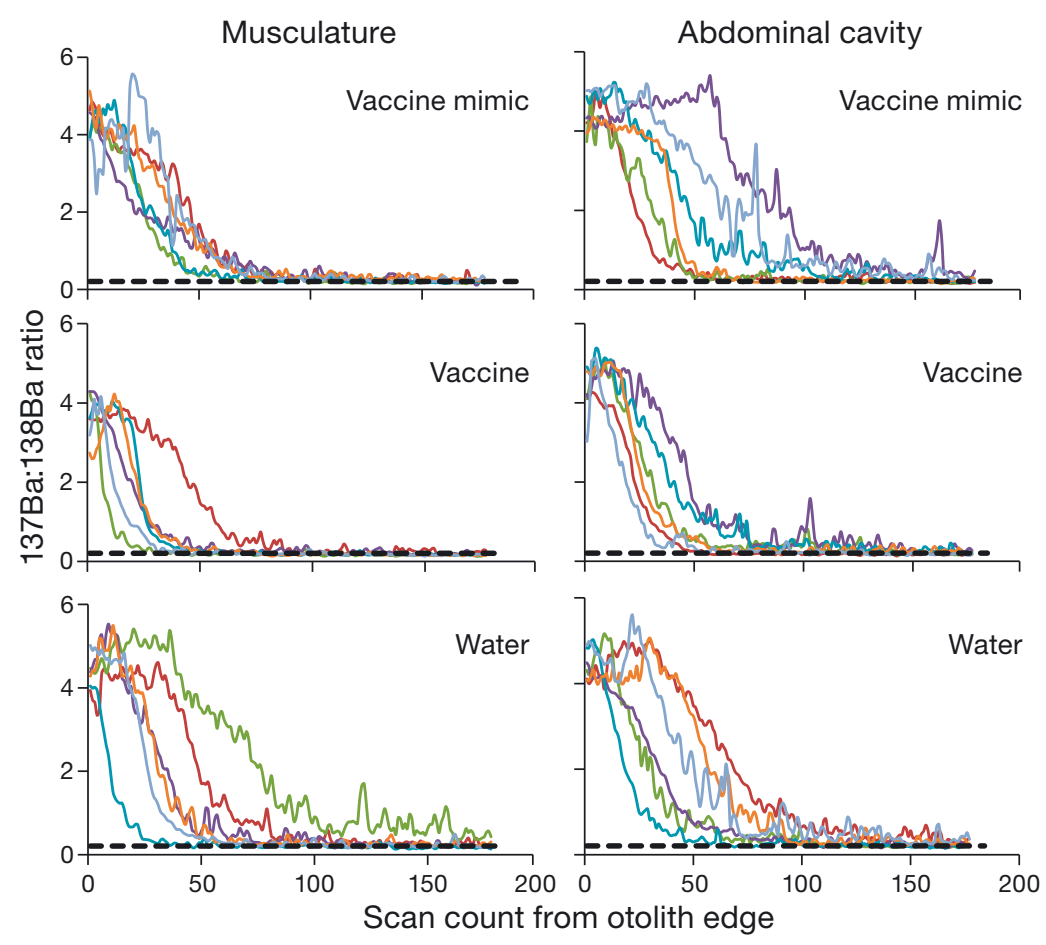

Fig. 1. Salmo salar. Mark success with ${ }^{137} \mathrm{Ba}:{ }^{138} \mathrm{Ba}$ for the 6 enrichment treatments. Treatments differed in the isotopic carrier solution used (vaccine mimic, vaccine, water) and the injection location (musculature or abdominal cavity). Coloured lines represent individual Atlantic salmon. Black dashed line represents average control ratio + 3.3 SDs. A scan is defined as a single laser ablation data point 

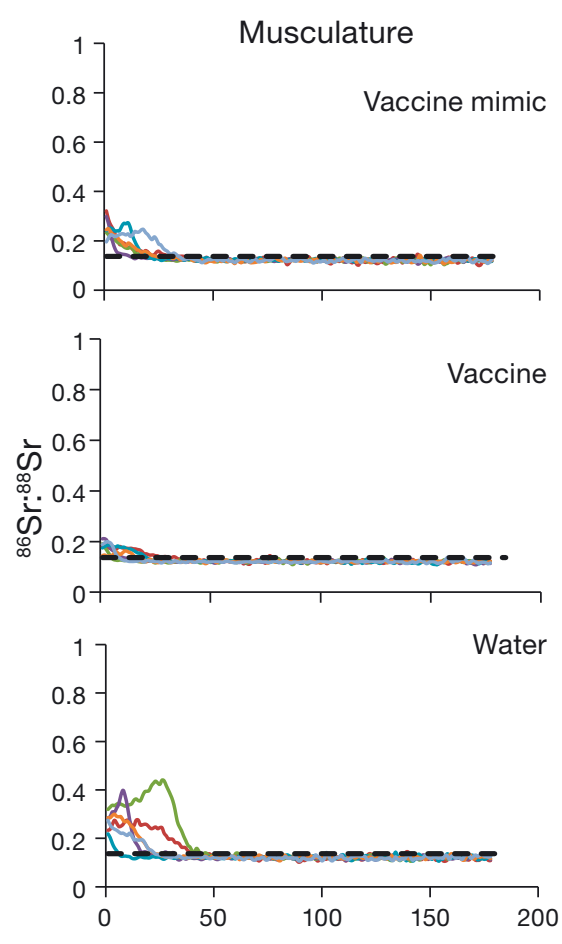

Scan count from otolith edge

Fig. 2. Salmo salar. Mark success with ${ }^{86} \mathrm{Sr}:{ }^{88} \mathrm{Sr}$ for the 6 enrichment treatments. Details as in Fig. 1
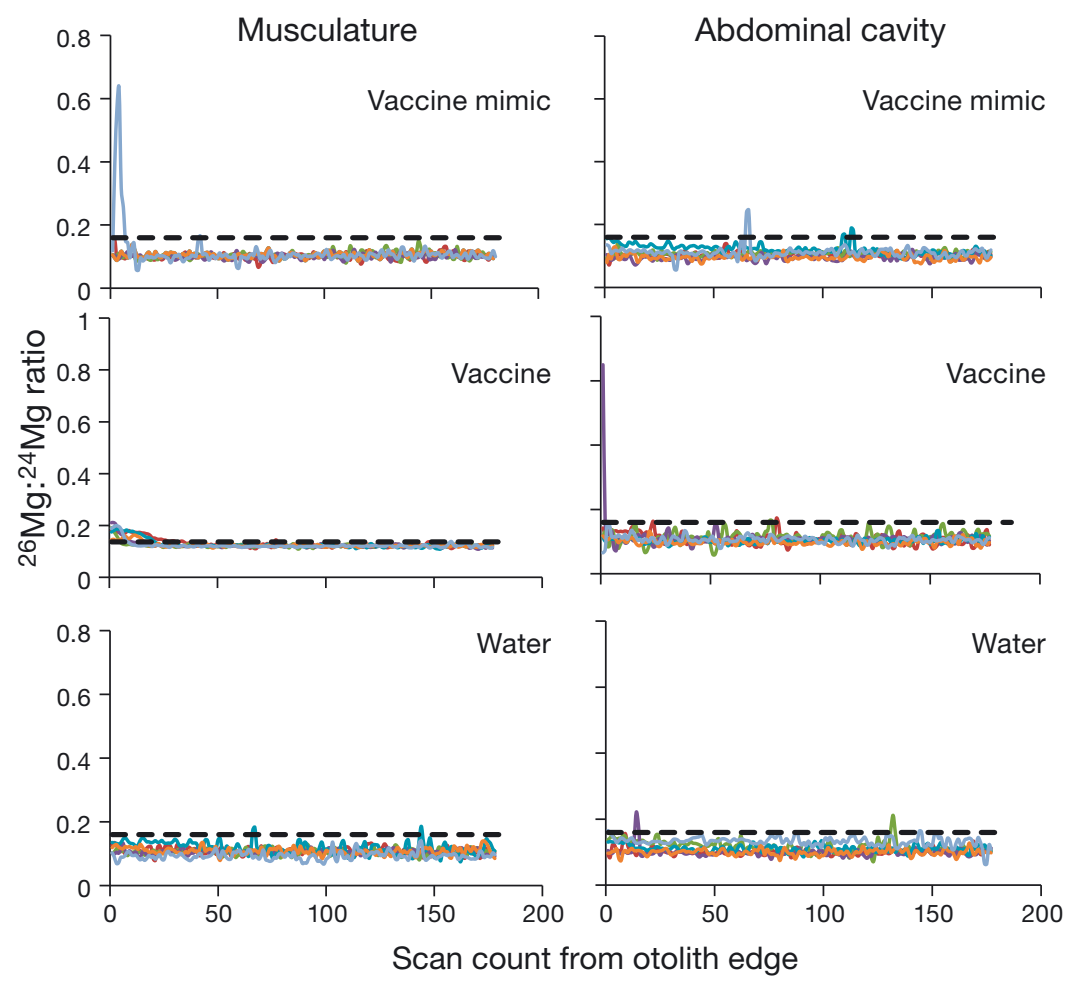

Fig. 3. Salmo salar. Mark success with ${ }^{26} \mathrm{Mg}:{ }^{24} \mathrm{Mg}$ for the 6 enrichment treatments. Details as in Fig. 1
0.001). Maximum ratios did not differ between enriched and non-enriched treatments for ${ }^{26} \mathrm{Mg}:{ }^{24} \mathrm{Mg}\left({ }^{26} \mathrm{Mg}\right.$ enrichment ratio: $0.19 \pm 0.02$, nonenrichment ratio: $0.16 \pm 0.02, F_{1,69}=$ 1.2, $\mathrm{p}=0.3$ ).

An effect of carrier solution was found for ${ }^{137} \mathrm{Ba}:{ }^{138} \mathrm{Ba}\left(F_{2,69}=3.5, \mathrm{p}=\right.$ $0.04)$, with maximum ratio values higher for VM compared to V (VM: $2.75 \pm 0.06 ; \mathrm{V}: 2.53 \pm 0.06 ; \mathrm{W}: 2.60 \pm$ 0.06; post hoc Tukey HSD: VM $>\mathrm{V}$; $\mathrm{p}=$ 0.04). Conversely, there was no effect of carrier solution on ${ }^{86} \mathrm{Sr}:{ }^{88} \mathrm{Sr}\left(F_{2,69}=\right.$ $0.34, \mathrm{p}=0.7)$ or ${ }^{26} \mathrm{Mg}:{ }^{24} \mathrm{Mg}$ ratios $\left(F_{2,69}=0.6, \mathrm{p}=0.6\right)$.

Injection location influenced the maximum isotope ratios values for ${ }^{86} \mathrm{Sr}:{ }^{88} \mathrm{Sr}$ and ${ }^{137} \mathrm{Ba}:{ }^{138} \mathrm{Ba}\left(F_{1,69}=12, \mathrm{p}=0.001\right.$; and $F_{1,69}=5.3, \mathrm{p}=0.03$; respectively). For $\mathrm{Sr}$, the maximum ratio was 1.4 times higher in otoliths from AC- than M-injected fish (AC: $0.27 \pm 0.02 ; \mathrm{M}$ : $0.20 \pm 0.02$ ). For $\mathrm{Ba}$, the maximum ratio was 1.07 times higher for $\mathrm{AC}$ compared to M-injected fish (AC: 2.61 \pm 0.05 ; M: $2.44 \pm 0.05)$. There was no difference in maximum ratios between injection locations for ${ }^{26} \mathrm{Mg}$ : ${ }^{24} \mathrm{Mg}\left(F_{1,69}=0.03, \mathrm{p}=0.9\right)$.

Several 2-way interactions occurred between factors for the $\mathrm{Sr}$ and $\mathrm{Ba}$ maximum ratios. An Enrichment $\times$ Injection location interaction occurred for both ${ }^{86} \mathrm{Sr}:{ }^{88} \mathrm{Sr}\left(F_{1,69}=12, \mathrm{p}=0.001\right)$ and ${ }^{137} \mathrm{Ba}:{ }^{138} \mathrm{Ba}\left(F_{1,69}=5.9, \mathrm{p}=0.02\right)$, with AC-injected enrichment treatments returning higher ratios compared to M-injected enrichment treatments (Figs. 4 \& 5). In addition, there was an Enrichment $\times$ Carrier solution interaction for ${ }^{137} \mathrm{Ba}:{ }^{138} \mathrm{Ba}\left(F_{2,69}=4.1, \mathrm{p}=\right.$ $0.02)$, with higher maximum ratios occurring in enrichment treatments for carrier solutions VM and W compared to $\mathrm{V}$.

\section{Strength of isotope enrichment}

Analysis of the number of scans and average ratio of scans above the detection limit were only analysed for ${ }^{137} \mathrm{Ba}$ : 


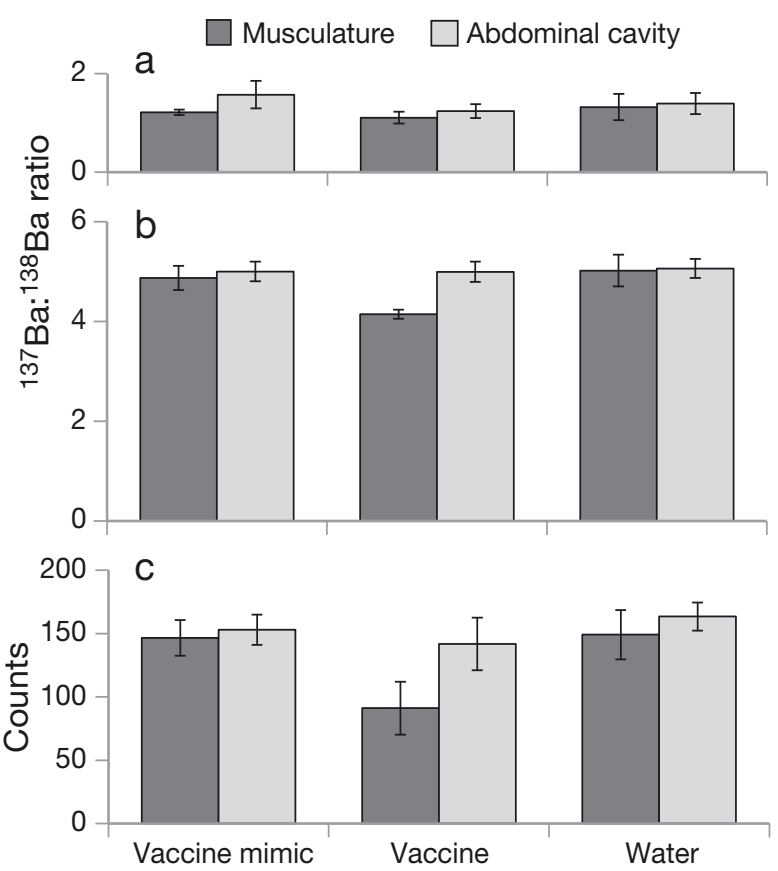

Fig. 4. Salmo salar. Strength of mark uptake with ${ }^{137}$ Ba enrichment. Bar graphs show: (a) average ratio, (b) maximum ratio for scans above detection limit, and (c) number of scans above detection limit. Error bars represent $\pm 1 \mathrm{SE}$
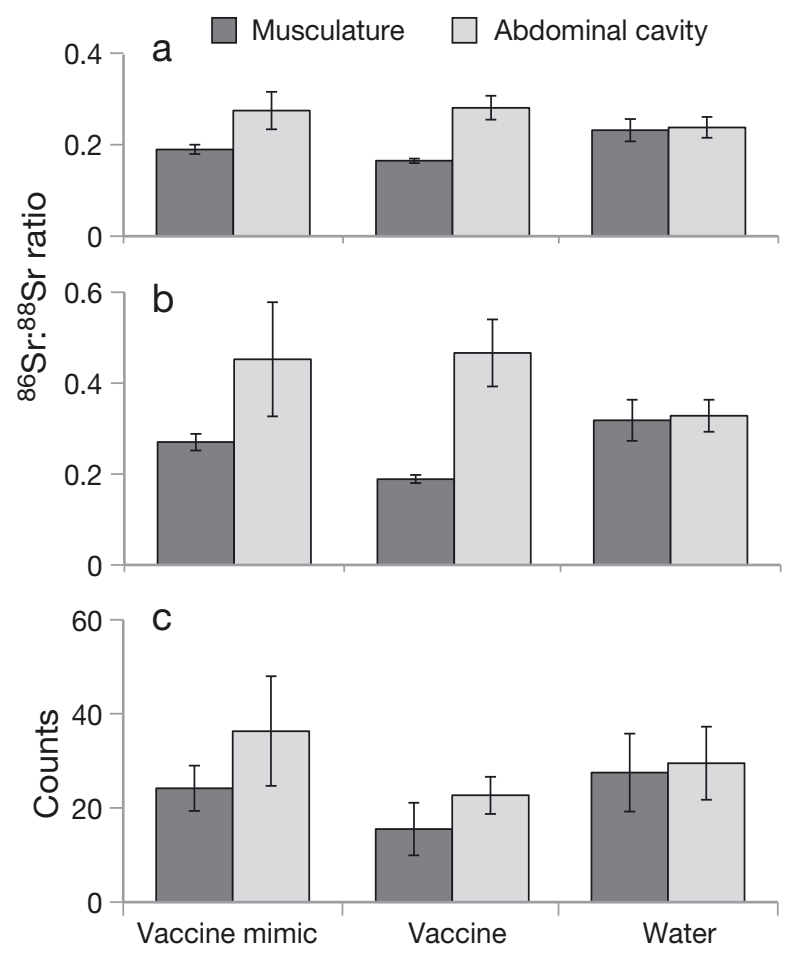

Fig. 5. Salmo salar. Strength of mark uptake with ${ }^{86} \mathrm{Sr}$ enrichment. Bar graphs show: (a) average ratio, (b) maximum ratio for scans above detection limit, and (c) number of scans above detection limit. Error bars represent $\pm 1 \mathrm{SE}$
${ }^{138} \mathrm{Ba}$ and ${ }^{86} \mathrm{Sr}:{ }^{88} \mathrm{Sr}$, as the ${ }^{26} \mathrm{Mg}:{ }^{24} \mathrm{Mg}$ enrichment did not produce enough scans with ratios above the detection limit to warrant further analyses. For the number of scans above the detection limit, carrier solution and injection location affected the strength of the ${ }^{137} \mathrm{Ba}:{ }^{138} \mathrm{Ba}$ isotope enrichment (carrier solution: $F_{2,35}=6.4, \mathrm{p}=0.005$; injection location: $F_{1,35}=$ $5.6, p=0.03$; Fig. 4). AC returned a greater number of scans above the detection limit than $\mathrm{M}$ injection, and the VM and $\mathrm{W}$ carrier solutions returned a greater number of scans above the detection limit compared to $\mathrm{V}$ (post hoc Tukey HSD: VM $>\mathrm{V}, \mathrm{p}=0.02$; W $>\mathrm{V}$, $p=0.006)$. No difference was found for the number of scans between enrichment treatments for carrier solution or injection location for ${ }^{86} \mathrm{Sr}:{ }^{88} \mathrm{Sr}$ (carrier solution: $F_{2,35}=0.1, \mathrm{p}=0.09$; injection location: $F_{1,35}=$ 3.1, $\mathrm{p}=0.09$; Fig. 5).

Average ratios for scans above the detection limit highlighted the importance of injection location when using Sr isotope enrichment; AC produced a higher mean ratio than $\mathrm{M}$ injection for ${ }^{86} \mathrm{Sr}:{ }^{88} \mathrm{Sr}$ (AC: $0.26 \pm$ 0.11 [mean $\pm \mathrm{SE}$ ]; $\mathrm{M}: 0.19 \pm 0.11 ; F_{1,35}=18, \mathrm{p}<0.001$ ). In addition, an interaction between carrier solution and injection location for ${ }^{86} \mathrm{Sr}:{ }^{88} \mathrm{Sr}\left(F_{2,35}=3.7, \mathrm{p}=\right.$ $0.04)$ showed there was higher average isotope uptake for VM and V compared to W with AC compared to $M$ injection (Fig. 5). No differences in the average ratio for scans above the detection limit were found between carrier solutions or injection locations for ${ }^{137} \mathrm{Ba}:{ }^{138} \mathrm{Ba}$ (carrier solution: $F_{2,35}=1.3, \mathrm{p}=0.3$; injection location: $F_{1,35}=3.2, \mathrm{p}=0.09$ ) (Fig. 4).

\section{Effect of treatment on mortality and condition}

No signs of morbidity or mortalities were recorded during the experiment and there were no detectable changes in fish condition due to isotope enrichment, injection location, or carrier solution (Fulton's condition factor $K$ : enrichment: $F_{1,71}=0.4, \mathrm{p}=0.5$; injection location: $F_{1,71}=1.2, \mathrm{p}=0.3$; carrier solution: $F_{2,71}=$ $0.9, \mathrm{p}=0.4$ ).

\section{Baseline isotope ratios for Atlantic salmon in Norwegian rivers}

Baseline ratios for ${ }^{137} \mathrm{Ba}:{ }^{138} \mathrm{Ba},{ }^{86} \mathrm{Sr}:{ }^{88} \mathrm{Sr}$ and ${ }^{26} \mathrm{Mg}:{ }^{24} \mathrm{Mg}$ varied little across the 22 rivers surveyed (Fig. 6; Table A1 in the Appendix). Among-river ratios ranged from 0.156 to 0.159 for ${ }^{137} \mathrm{Ba}:{ }^{138} \mathrm{Ba}, 0.108$ to 0.121 for ${ }^{86} \mathrm{Sr}:{ }^{88} \mathrm{Sr}$, and 0.086 to 0.136 for ${ }^{26} \mathrm{Mg}:{ }^{24} \mathrm{Mg}$. In addition, baseline ratios varied little among the 6 random years between 1990 and 2010 analysed from 


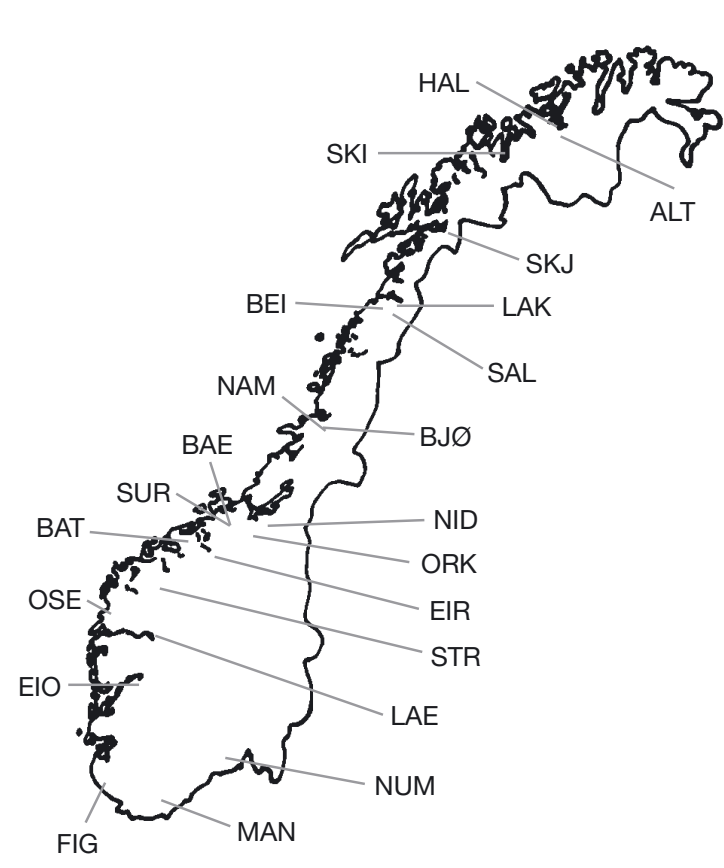

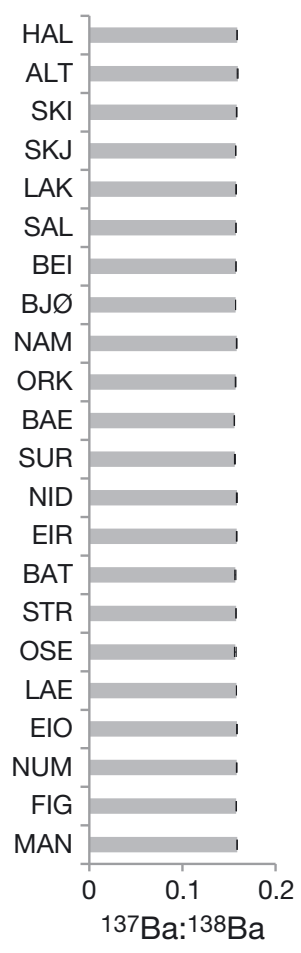

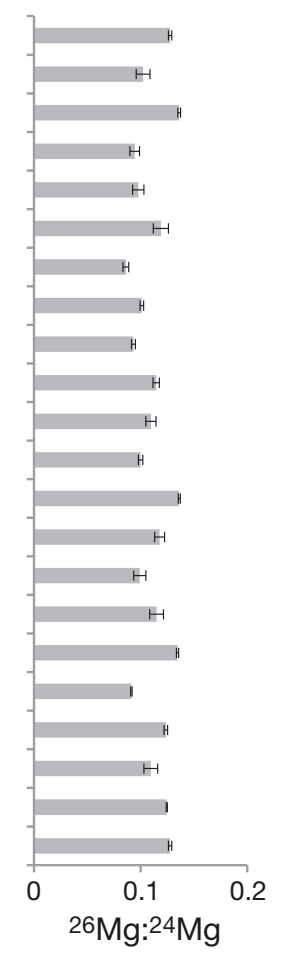

Fig. 6. Baseline isotope ratios of Norwegian Salmo salar parr surveyed from 22 rivers across Norway. Bars represent the average ratios of 3 fish from each river sampled, except for Saltdalselva (SAL) and Strynselva (STR), where bars represent the average ratios of 18 fish sampled between 1990 and 2010. Error bars represent \pm 1 SE. See Table A1 in the Appendix for abbreviations

each of the Saltdalselva and Strynselva rivers (Table A2 in the Appendix). Among-year ratios ranged from 0.157 to 0.158 for ${ }^{137} \mathrm{Ba}:{ }^{138} \mathrm{Ba}, 0.109$ to 0.121 for ${ }^{86} \mathrm{Sr}:{ }^{88} \mathrm{Sr}$, and 0.094 to 0.131 for ${ }^{26} \mathrm{Mg}:{ }^{24} \mathrm{Mg}$. The range of baseline ratios, among rivers and years, were all within the mean $\pm 2.5 \mathrm{SD}$ of control ratios observed in the vaccination trial (vaccine control ratios: ${ }^{137} \mathrm{Ba}:{ }^{138} \mathrm{Ba}: 0.158 \pm 0.037 ;{ }^{86} \mathrm{Sr}:{ }^{88} \mathrm{Sr}: 0.121 \pm$ $\left.0.012{ }^{26} \mathrm{Mg}:{ }^{24} \mathrm{Mg}: 0.103 \pm 0.035\right)$. This suggests that unmarked farmed Atlantic salmon parr have similar isotopic ratios to that of wild Atlantic salmon in the rivers of Norway. Therefore, all wild salmon had otolith isotope ratios that would be scored as unmarked using our method.

\section{DISCUSSION}

Injecting with enriched ${ }^{137} \mathrm{Ba}$ and ${ }^{86} \mathrm{Sr}$ was $100 \%$ effective in significantly changing the ${ }^{137} \mathrm{Ba}:{ }^{138} \mathrm{Ba}$ and ${ }^{86} \mathrm{Sr}:{ }^{88} \mathrm{Sr}$ ratios in the otoliths of farmed Atlantic salmon parr for both injection locations (AC and $\mathrm{M}$ ) and with all 3 carrier solutions (W, V and VM). In addition, stable isotope enrichment appears to have no short-term effects on fish condition or survival rate. Furthermore, the $\mathrm{Ba}$ and $\mathrm{Sr}$ isotope ratios created in marked experimental farmed fish in this study were uniquely different from observed natural ratios of $\mathrm{Ba}$ and $\mathrm{Sr}$ in wild salmon parr from the 22 rivers across Norway. These findings indicate that mass-marking with $\mathrm{Ba}$ and $\mathrm{Sr}$ stable isotopes via vaccination injection has the potential to be a $100 \%$ effective fish-identification technique. Furthermore, this technique could be developed to produce multielemental fingerprint codes in otoliths. If adopted at a whole-of-industry scale, this technique could be used to differentiate farmed and wild fish and to identify the source farm of escaped Atlantic salmon.

\section{Mark success}

An unambiguous mark is critical for accurate fish identification, particularly when low numbers of tagged fish are caught during mark-recapture surveys. Here, $100 \%$ mark success was achieved using enriched ${ }^{137} \mathrm{Ba}$ and ${ }^{86} \mathrm{Sr}$ at a concentration of $2 \mu \mathrm{g}$ of isotope per gram of average fish weight. Other research has shown 100\% mark success can be achieved using lower concentrations of stable isotope when using a transgenerational isotope marking technique, such as $0.5 \mu \mathrm{g}$ of ${ }^{137} \mathrm{Ba}$ per gram brood fish in brown-marbled groper Epinephelus fuscoguttatus (Williamson et al. 2009b) and $0.3 \mu \mathrm{g}$ of ${ }^{137} \mathrm{Ba}$ per 
gram brood fish in brown trout Salmo trutta (HuelgaSuarez et al. 2012). Hence, it may be possible to use ${ }^{137} \mathrm{Ba}$ and ${ }^{86} \mathrm{Sr}$ isotopes at 10 to 100 times lower concentrations and still achieve $100 \%$ mark success via vaccination, which would greatly reduce the amount of isotope, and thus cost, required for marking.

Mark success for ${ }^{26} \mathrm{Mg}$ was poor and varied greatly across treatments ( 0 to $34 \%$ ), indicating that ${ }^{26} \mathrm{Mg}$ enrichment is not suitable for marking parr. The mark success rate for $\mathrm{Mg}$ observed in this experiment is lower compared to that of Woodcock et al. (2011a), who tagged golden perch Macquaria ambigua with ${ }^{26} \mathrm{Mg}$ and achieved approximately $60 \%$ mark success using a larval immersion technique. Mg appears to be self-regulated in salmonids and may be sourced from either food or water (Shearer \& Åsgård 1992). In addition, Mg has a slow exchange rate in body tissue compared to calcium, and only 1 to $2 \%$ of $\mathrm{Mg}$ ions are transported into the endolymph fluid (Maguire \& Cowan 2002) in which otoliths are encapsulated. A combination of these factors and the likelihood that farmed fed salmon parr used in our experiment were not deficient in total Mg suggests that either a concentration of $2 \mu \mathrm{g} \mathrm{g}^{-1}$ fish mass of ${ }^{26} \mathrm{Mg}$ was insufficient for achieving $100 \%$ mark success, or the time between injection and sampling of the otoliths may have been too short (14 d) for sufficient uptake of ${ }^{26} \mathrm{Mg}$ to occur.

\section{Mark strength}

We quantified the strength of the isotope markers by comparing the average ratio and total number of scans above the threshold ratio in each enrichment treatment. Overall, injection into the abdominal cavity returned stronger and more consistent marks for ${ }^{137} \mathrm{Ba}$ and ${ }^{86} \mathrm{Sr}$ compared to injecting into the musculature. This may simply be due to better retention of the carrier solutions in the abdominal cavity compared to the musculature. Leakage of the solution from the musculature injection site was observed post-injection, whereas no visible leakage occurred for the abdominal cavity injection site (F. Warren-Myers \& T. Dempster pers. obs.). An alternate possibility is that the biological pathways for Ba and Sr ion transport from the abdominal cavity to the endolymph fluid surrounding the otolith may be more efficient or direct compared to ion transport from musculature tissue.

The strength of mark uptake for ${ }^{137} \mathrm{Ba}$ and ${ }^{86} \mathrm{Sr}$ enrichment was influenced by carrier solution in addition to injection location by the number of scans with ratios above detection, but not the average ratio of scans above detection. The number of scans with ratios above the detection limit suggests carrier solutions that contained $50 \%(\mathrm{VM})$ and $100 \%$ (W) water produced a stronger mark than $\mathrm{V}(3.5 \%$ water $)$ for ${ }^{137} \mathrm{Ba}:{ }^{138} \mathrm{Ba}$, which may imply that water is a more efficient medium for delivering barium isotopes via injection. However, the opposite effect was found for ${ }^{86} \mathrm{Sr}:{ }^{88} \mathrm{Sr}$, with carrier solutions showing no difference in number of scans with ratios above the detection limit, but average ratios indicating carrier solutions with lower water content (VM: 50\%, and V: $3.5 \%$ ) may enhance strontium isotope enrichment.

\section{Fish condition and survival}

A mass-marking method that does not compromise fish health or growth rate is an ideal prerequisite for a marking programme. Parameters monitored in this trial to assess fish health (Fulton's condition factor $K$, survival rate) indicated there were no negative health effects of enriched stable isotope marking on Atlantic salmon parr $70 \mathrm{~d}$ post-injection. Previous experiments that have used stable isotopes to mark fish by other delivery methods, such as transgenerational and immersion, have similarly detected no negative short-term effects of stable isotope treatments on survival and growth (Munro et al. 2009, Williamson et al. 2009a, Woodcock et al. 2011a,b), although possible effects may occur for different fish species (Starrs et al. 2014). While we have no a priori reason to expect that stable isotope marking via vaccination injection should have any detrimental longterm effects on fish growth and condition in salmon, longer-term, larger-scale trials are required before the technique can be adopted as a mass-marking method for use on millions of fish.

\section{Baseline ratio comparisons}

Isotope ratios of ${ }^{137} \mathrm{Ba}:{ }^{138} \mathrm{Ba},{ }^{86} \mathrm{Sr}:{ }^{88} \mathrm{Sr}$ and ${ }^{26} \mathrm{Mg}:{ }^{24} \mathrm{Mg}$ are typically highly conserved in natural waters. This was reflected in the ratios observed in wild salmon parr collected from Norwegian rivers in both space (22 rivers) and time (1990 to 2010; Saltdalselva and Strynselva). Ratios varied by less than $2 \%$ for ${ }^{137} \mathrm{Ba}$ : ${ }^{138} \mathrm{Ba}$ and less than $10 \%$ for ${ }^{86} \mathrm{Sr}:{ }^{88} \mathrm{Sr}$. As natural variation of less than $3 \%$ in the isotope ratios of ${ }^{86} \mathrm{Sr}:{ }^{87} \mathrm{Sr}$ has been used to separate natal habitats in some fish species with up to $80 \%$ correct assignment (e.g. Kennedy et al. 2000, 2002, Veinott \& Porter 2005), our results suggest that $\mathrm{Sr}$ isotope ratios could be a useful 
tool for investigating migratory behaviour and the degree of philopatry in wild Atlantic salmon populations in Norway. Importantly, all natural background ratios were within 2.5 SDs of control fish analysed in the vaccination trial, indicating that no wild salmon would have been falsely assessed as being a marked farm-reared escapee. Conservatively, to ensure an artificial isotopic mark is not mistaken for a natural isotopic signature, the ratios in marked fish otoliths should be well above that of natural background variation to guarantee correct fish identification.

\section{Optimisation of enriched stable isotope otolith fingerprinting during vaccination}

In the present study, the enriched isotope treatments shifted the isotopic ratios of ${ }^{137} \mathrm{Ba}:{ }^{138} \mathrm{Ba}$ and ${ }^{86} \mathrm{Sr}:{ }^{88} \mathrm{Sr}$ by 2 to 3 orders of magnitude compared to the experimental controls and the natural baseline ratios. This is well above the conservative threshold of 3.3 SDs which we set as the level to determine mark success with $100 \%$ accuracy, which suggests the amount of isotope used for enrichment could be reduced. Optimisation of the minimum required concentration of isotopes needed to create a marker is required to confirm if this method is cost-effective for mass-marking, while still ensuring marks are uniquely different from wild salmon. Further investigation using the commercial vaccine MINOVA 6 with other isotopes, e.g. ${ }^{134} \mathrm{Ba},{ }^{135} \mathrm{Ba},{ }^{136} \mathrm{Ba}$ and ${ }^{87} \mathrm{Sr}$, would determine the feasibility of creating multiple combinations of stable isotope markers (e.g. Munro et al. 2008, Woodcock et al. 2011a,b) using the vaccinationbased delivery method.

\section{Application of enriched stable isotope otolith fingerprinting during vaccination}

Farmed fish, including salmon escape from aquaculture facilities and enter the wild $(\varnothing$. Jensen et al. 2010, Jackson et al. 2012, A. J. Jensen et al. 2013), with subsequent ecological and/or evolutionary effects on wild fish populations (Fleming et al. 2000, McGinnity et al. 2003). A marking technique that enabled tracing of escapees back to the farm of origin would provide greater insight into the causes of escape events (Jensen et al. 2010), better capacity for regulatory bodies to determine the level of underreporting, and improvement of enforcement of compliance measures (Fiske et al. 2006). An ideal marking technique should meet the following criteria: (1) sufficient unique marks to be useful at a whole-ofindustry scale; (2) $100 \%$ correct mark detection; (3) an efficient and cost-effective method of application; and (4) no negative side effects on production parameters or fish health. The stable isotope marking via vaccination technique trialled in this study has the potential to meet these criteria. If all fish in the salmon farming industry were vaccinated, isotope markers could be added during the vaccine production phase prior to being delivered to commercial farms, thus ensuring no extra manual labour costs to fish farmers for the purpose of marking and monitoring all farmed Atlantic salmon.

Acknowledgements. We thank Lise Dyrhovden and the technical staff from the Matre Aquaculture Research Station and Ingebrigt Uglem (NINA) for facilitating access to the Norwegian Institute for Nature Research Atlantic salmon archive. Alan Greig from the School of Earth Sciences, University of Melbourne, assisted with LA-ICP-MS analyses. Funding was provided by the Norwegian Fisheries and Aquaculture Research Fund (project \#900710).

\section{LITERATURE CITED}

Adey EA, Black KD, Sawyer T, Shimmield TM, Trueman CN (2009) Scale microchemistry as a tool to investigate the origin of wild and farmed Salmo salar. Mar Ecol Prog Ser 390:225-235

Almany GR, Berumen ML, Thorrold SR, Planes S, Jones GP (2007) Local replenishment of coral reef fish populations in a marine reserve. Science 316:742-744

Barbee NC, Swearer SE (2007) Characterizing natal source population signatures in the diadromous fish Galaxias maculatus, using embryonic otolith chemistry. Mar Ecol Prog Ser 343:273-282

Barnett-Johnson R, Ramos FC, Grimes CB, MacFarlane RB (2005) Validation of Sr isotopes in otoliths by laser ablation multicollector inductively coupled plasma mass spectrometry (LA-MC-ICPMS): opening avenues in fisheries science applications. Can J Fish Aquat Sci 62:2425-2430

> Barnett-Johnson R, Grimes CB, Royer CF, Donohoe CJ (2007) Identifying the contribution of wild and hatchery Chinook salmon (Oncorhynchus tshawytscha) to the ocean fishery using otolith microstructure as natural tags. Can J Fish Aquat Sci 64:1683-1692

> Bath GE, Thorrold SR, Jones CM, Campana SE, McLaren JW, Lam JWH (2000) Strontium and barium uptake in aragonitic otoliths of marine fish. Geochim Cosmochim Acta 64:1705-1714

Buckland-Nicks JA, Gillis M, Reimchen TE (2012) Neural network detected in a presumed vestigial trait: ultrastructure of the salmonid adipose fin. Proc R Soc Lond B Biol Sci 279:553-563

Campana SE (2005) Otolith elemental composition as a natural marker for fish stocks. In: Cadrin SX, Frieland KD, Waldman JR (eds) Stock identification methods: applications in fishery science. Elsevier Academic Press, Burlington, MA, p 227-245

$>$ Collins MR, Smith TIJ, Heyward LD (1994) Effectiveness of six methods for marking juvenile shortnose sturgeons. Prog Fish-Cult 56:250-254 
Crook DA, O'Mahony DJ, Sanger AC, Munro AR, Gillanders BM, Thurstan S (2009) Development and evaluation of methods for osmotic induction marking of golden perch Macquaria ambigua with calcein and alizarin red S. N Am J Fish Manag 29:279-287

Elsdon TS, Gillanders BM (2004) Fish otolith chemistry influenced by exposure to multiple environmental variables. J Exp Mar Biol Ecol 313:269-284

Farrell J, Campana SE (1996) Regulation of calcium and strontium deposition on the otoliths of juvenile tilapia, Oreochromis niloticus. Comp Biochem Physiol A 115:103-109

Fiske P, Lund RA, Hansen LP (2006) Relationships between the frequency of farmed Atlantic salmon, Salmo salar L., in wild salmon populations and fish farming activity in Norway, 1989-2004. ICES J Mar Sci 63:1182-1189

> Fleming IA, Hindar K, Mjølnerød IB, Jonsson B, Balstad T, Lamberg A (2000) Lifetime success and interactions of farm salmon invading a native population. Proc R Soc Lond B Biol Sci 267:1517-1523

Gillanders BM (2005) Using elemental chemistry of fish otoliths to determine connectivity between estuarine and coastal habitats. Estuar Coast Shelf Sci 64:47-57

> Glover KA (2010) Forensic identification of fish farm escapees: the Norwegian experience. Aquacult Environ Interact 1:1-10

Glover KA, Skilbrei OT, Skaala Ø (2008) Genetic assignment identifies farm of origin for Atlantic salmon Salmo salar escapees in a Norwegian fjord. ICES J Mar Sci 65:912-920

> Huelga-Suarez G, Moldovan M, Garcia-Valiente A, GarciaVazquez E, Garcia Alonso JI (2012) Individual-specific transgenerational marking of fish populations based on a barium dual-isotope procedure. Anal Chem 84:127-133

Jackson D, Drumm A, McEvoy S, Jensen Ø and others (2012) Chapter 2. A pan-European evaluation of the extent, causes and cost of escape events from sea-cage fish farming. In: PREVENT ESCAPE Project Compendium. 7th Research Framework Program, Commission of the European Communities, Brussels. www.preventescape.eu

> Jensen Ø, Dempster T, Thorstad EB, Uglem I, Fredheim A (2010) Escapes of fishes from Norwegian sea-cage aquaculture: causes, consequences and prevention. Aquacult Environ Interact 1:71-83

> Jensen AJ, Karlsson S, Fiske P, Hansen LP, Hindar K, Østborg GM (2013) Escaped farmed Atlantic salmon grow, migrate and disperse throughout the Arctic Ocean like wild salmon. Aquacult Environ Interact 3:223-229

> Jones GP, Milicich MJ, Emsile MJ, Lunow C (1999) Selfrecruitment in a coral reef fish population. Nature 402: 802-804

Kalish JM (1990) Use of otolith microchemistry to distinguish the progeny of sympatric anadromous and nonanadromous salmonids. Fish Bull 88:657-666

Kennedy BP, Blum JD, Folt CL, Nislow KH (2000) Using natural strontium isotopic signatures as fish markers: methodology and application. Can J Fish Aquat Sci 57: 2280-2292

Kennedy BP, Klaue A, Blum JD, Folt CL, Nislow KH (2002) Reconstructing the lives of fish using $\mathrm{Sr}$ isotopes in otoliths. Can J Fish Aquat Sci 59:925-929

Maguire ME, Cowan JA (2002) Magnesium chemistry and biochemistry. Biometals 15:203-210

McGinnity P, Prodohl P, Ferguson A, Hynes R and others (2003) Fitness reduction and potential extinction of wild populations of Atlantic salmon, Salmo salar, as a result of interactions with escaped farm salmon. Proc R Soc Lond B Biol Sci 270:2443-2450

Munro AR, McMahon TE, Leathe SA, Liknes G (2003)
Evaluation of batch marking small rainbow trout with coded wire tags. N Am J Fish Manag 23:600-604

Munro AR, Gillanders BM, Elsdon TS, Crook DA, Sanger AC (2008) Enriched stable isotope marking of juvenile golden perch (Macquaria ambigua) otoliths. Can J Fish Aquat Sci 65:276-285

> Munro AR, Gillanders BM, Thurstant S, Crook DA, Sanger AC (2009) Transgenerational marking of freshwater fishes with enriched stable isotopes: a tool for fisheries management and research. J Fish Biol 75:668-684

> Serafy JE, Lutz SJ, Capo TR, Ortner PB, Lutz PL (1995) Anchor tags affect swimming performance and growth of juvenile red drum (Sciaenops ocellatus). Mar Freshw Behav Physiol 27:29-35

> Shearer KD, Åsgård T (1992) The effect of water-borne magnesium on the dietary magnesium requirement of the rainbow trout (Oncorhynchus mykiss). Fish Physiol Biochem 9:387-392

Smith KT, Whitledge GW (2011) Evaluation of a stableisotope labelling technique for mass marking fin rays of age-0 lake sturgeon. Fish Manag Ecol 18:168-175

> Starrs D, Davis JT, Schlaefer J, Ebner BC, Eggins SM, Fulton CJ (2014) Maternally transmitted isotopes and their effects on larval fish: a validation of dual isotopic marks within a meta-analysis context. Can J Fish Aquat Sci 71:387-397

Swearer SE, Caselle JE, Lea DW, Warner RR (1999) Larval retention and recruitment in an island population of a coral reef fish. Nature 402:799-802

> Thorrold SR, Jones GP, Planes S, Hare JA (2006) Transgenerational marking of embryonic otoliths in marine fishes using barium stable isotopes. Can J Fish Aquat Sci 63: 1193-1197

Vander Haegen GE, Blankenship HL, Hoffmann A, Thompson DA (2005) The effects of adipose fin clipping and coded wire tagging on the survival and growth of spring chinook salmon. N Am J Fish Manag 25:1161-1170

Veinott G, Porter R (2005) Using otolith microchemistry to distinguish Atlantic salmon (Salmo salar) parr from different natal streams. Fish Res 71:349-355

> Volk EC, Schroder SL, Grimm JJ (1999) Otolith thermal marking. Fish Res 43:205-209

- Walther BD, Limburg KE (2012) The use of otolith chemistry to characterize diadromous migrations. J Fish Biol 81: 796-825

> Williamson DH, Jones GP, Thorrold SR, Frisch AJ (2009a) Transgenerational marking of marine fish larvae: stable isotope retention, physiological effects and health issues. J Fish Biol 74:891-905

> Williamson DH, Jones GP, Thorrold SR (2009b) An experimental evaluation of transgenerational isotope labelling in a coral reef grouper. Mar Biol 156:2517-2525

> Woodcock SH, Gillanders BM, Munro AR, McGovern F, Crook DA, Sanger AC (2011a) Using enriched stable isotopes of barium and magnesium to batch mark otoliths of larval golden perch (Macquaria ambigua, Richardson). Ecol Freshw Fish 20:157-165

Woodcock SH, Gillanders BM, Munro AR, Crook DA, Sanger AC (2011b) Determining mark success of 15 combinations of enriched stable isotopes for the batch marking of larval otoliths. N Am J Fish Manag 31:843-851

- Woodcock SH, Munro AR, Crook DA, Gillanders BM (2012) Incorporation of magnesium into fish otoliths: determining contribution from water and diet. Geochim Cosmochim Acta 94:12-21

> Woodcock SH, Grieshaber CA, Walther BD (2013) Dietary transfer of enriched stable isotopes to mark otoliths, fin rays and scales. Can J Fish Aquat Sci 70:1-4 


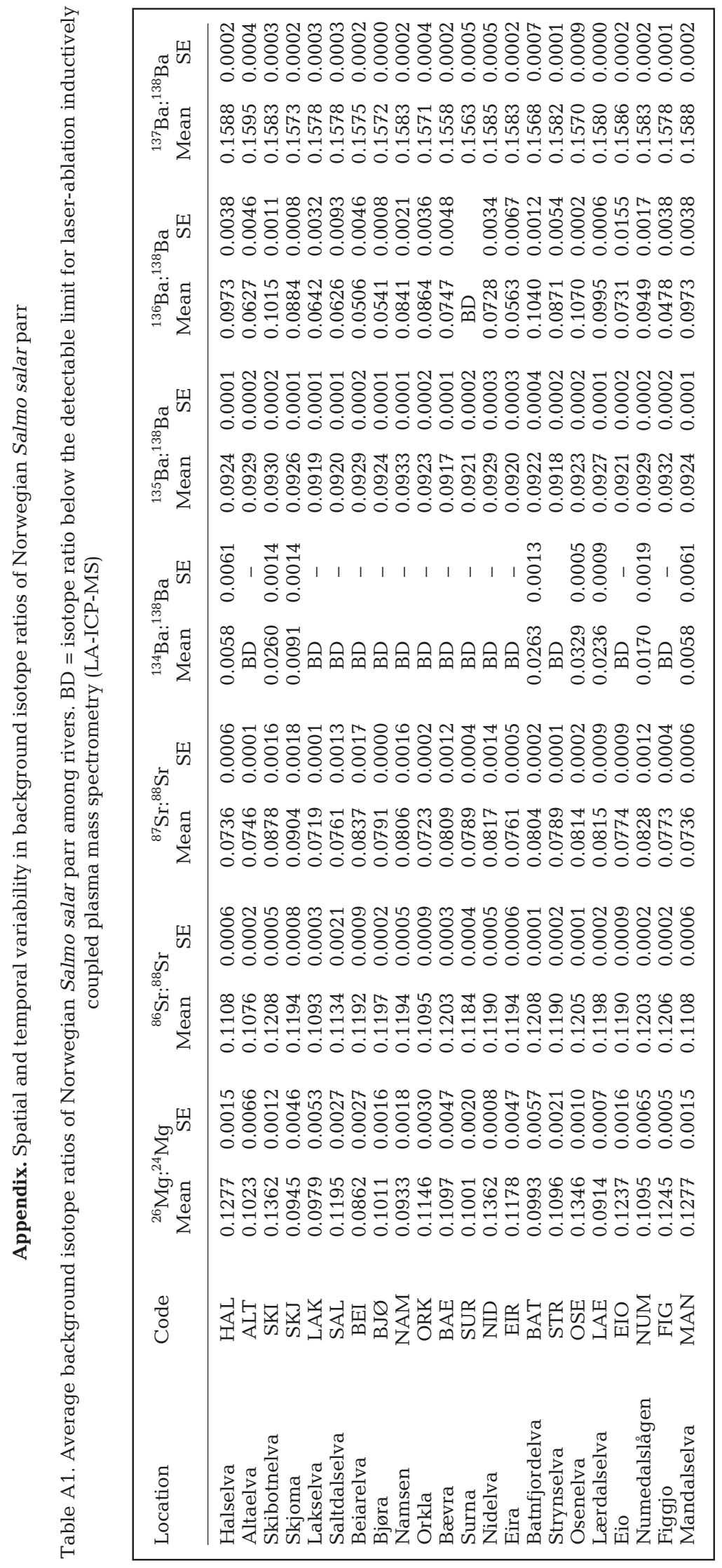

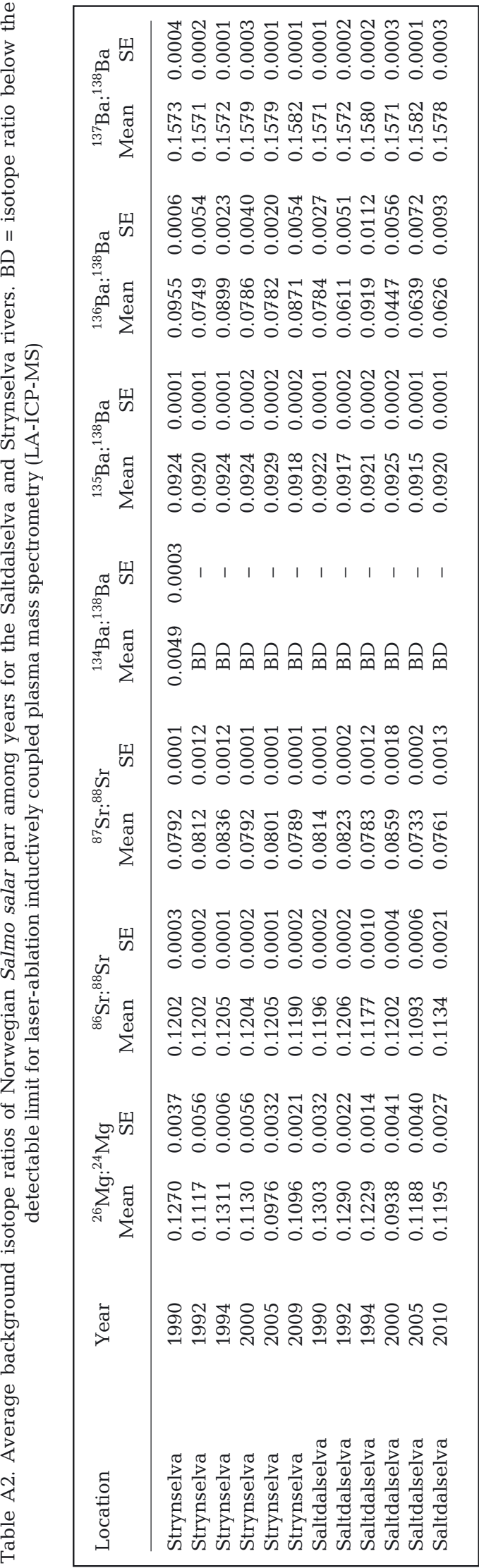

